\title{
Local knowledge of the community in Cintaratu Village, Pangandaran, Indonesia on traditional landscapes for sustainable land management
}

\author{
RUHYAT PARTASASMITA`, NADYA TIMURIA CAHYANI, JOHAN ISKANDAR \\ Department of Biology, Faculty of Mathematics and Natural Sciences, Universitas Padjadjaran. J1. Raya Bandung-Sumedang Km 21, Jatinangor, \\ Sumedang 45363, West Java, Indonesia. Tel.: +62-22-7796412 ext. 104, Fax.: +62-22-7794545, `email: rp2010rikkyo@ gmail.com; \\ ruhyat.partasasmita@unpad.ac.id
}

Manuscript received: 24 November 2019. Revision accepted: 17 July 2020.

\begin{abstract}
Partasasmita R, Cahyani NT, Iskandar J. 2020. Local knowledge of the community in Cintaratu Village, Pangandaran, Indonesia on traditional landscapes for sustainable land management. Biodiversitas 21: 3606-3616. Cintaratu, a village in Parigi Subdistrict, Pangandaran District, West Java province, Indonesia has various landscapes. The recent developments of the community reflect a shift in values towards the attainment of economic prosperity. However, scaling-up the use of landscapes in this capacity can cause negative impacts. A cultural approach to landscape management can assist the village community in identifying sustainable practices. The purpose of this study was to elucidate the community's knowledge of the variety of traditional landscapes that exist in Cintaratu Village and the historical influence on variations in the landscapes. The qualitative method was applied in this study. The result of the study showed that some landscapes, i.e., leuweung karamat (sacred forest), kebon (garden), sawah (rice field), astana (grave/ tomb), pamukiman (residential area), pekarangan (homegarden), walungan (river), solokan (small river), tampian (bathing and washing place for residents), and balong (fish pond) are documented in Cintaratu Village. On the basis of ecological history, it has been revealed that village community's behaviors have changed various landscapes in Cintaratu Village. Conservation efforts carried out by the people themselves towards the traditional landscapes are usually associated with a customary prohibition or pamali that develops in the village community. The local people of Cintaratu recognize various landscapes that can be classified as natural and cultural landscapes. Based on the information provided by informants, the village landscape changes can be traced from the 1780s to 2019. The history of these landscape changes is the result of various factors, including an increase in population density, the implementation of government policies, and market economic development in the village.
\end{abstract}

Keywords: Cintaratu, landscape management, landscape history, human activities, landscape variations

\section{INTRODUCTION}

In the $21^{\text {st }}$ century, most people tend to use the landscape only to meet economic needs, often ignoring traditional landscape values held by the local village community. In some areas, changes in the function of the landscape often show negative impacts, i.e., the disruption of environmental balance (Iskandar and Iskandar 2017; Partasasmita et al. 2016.). For example, sloped forest areas are often converted into agroecosystems of vegetable crops, with a terracing pattern that cuts contours (Rusdi et al. 2013; Oksana et al. 2012). Such patterns of landscape use on a large scale can cause negative impacts on the environment, such as accelerating the loss of soil fertility, increasing erosion rates, and even landslides, resulting in unsustainable land use (Antoko et al. 2008; Verbist et al. 2004; Hreško et al. 2010). Therefore, a cultural approach in managing biological resources may identify factors that, if implemented, can ensure the sustainable use of natural resources (Droste et al. 1995; Antrop1997; Mojses and Petrovič 2013).

Traditional people, especially the Sundanese villagers, are very concerned about the harmony between humans and their environment in the placement of various types of landscapes and cultures. For example, in the life of the Baduy people, in South Banten who are oriented to nature, the culture that develops in the community is very much related to natural conditions (Pratami and Pramukanto 2017). If there is a change in the type of landscape which is a modification due to human cultural life, then this change can be distinguished from the natural landscape, such as forests and rivers. For example, according to Iskandar and Iskandar (2017), traditional landscapes in traditional communities could be divided into four types, namely forests, swidden fields, gardens, and settlements, while Pratami and Pramukanto (2017) categorizes them into six categories, namely settlements, swidden fields (huma), fallowed huma just harvested (jami), village forests (leuweung lembur), mature secondary forests (reuma kolot), and protected forests (leuweung kolot). These types of landscapes have been traditionally managed by the Baduy community based on Traditional Ecological Knowledge (TEK) and belief (cf. Berkes 2008; Iskandar 2018; Iskandar et al. 2018). As a result, the Baduy continue to practice shifting cultivation (ngahuma), despite population growth and reduction of forest around them (Iskandar and Iskandar 2017) because people's knowledge of nature itself can produce a modified landscape following the cultural background and ideas of the community (Sauer 1963; Agnoletti 2014). The anthropogenic landscapes or anthropogenic biomes, also known as anthromes are built together by many species through complex ecological, economic, historical, and individual networks, so they 
appear geographically, culturally, and ecologically different (Johnson and Hunn 2012; Fuentes and BaynesRock 2017). The relationship between land, water, plants, animals, and human knowledge of nature is very important in forming anthropogenic landscapes (Rahman 1984; Davidson-Hunt 2003; Partasasmita et al. 2016).

Anthropogenic landscapes and their complexity in rural communities that hold only some parts of their tradition, such as Karangwangi Village, Cianjur District, West Java, Indonesia (Amelia et al. 2018), and do not have customary elders who know customary rules, such as in the Baduy, South Banten, and Kasepuhan, South Sukabumi, are expected to change quickly over time due to the introduction of technology and increasing knowledge of the people. For example, the landscape in Karangwangi Village underwent a landscape change between the 1950s and 2017 (Amelia et al. 2018), and a very striking change between the 1980s and 2017. Landscape changes are likely to occur in other villages in the West Java region, especially those undergoing tourism-related developments. Cintaratu Village is known as a non-traditional village in Parigi Sub-district, Pangandaran District, West Java. Based on this location Cintaratu Village has great potential to become a tourist village because it is close to Pangandaran beach and Pananjung Pangandaran Nature Reserve. Cintaratu Village has various types of landscapes that have been utilized by its people since time immemorial. Recently, the village has been developed by a mix of local and non-local actors (e.g., a large number of migrants from urban areas). The utilization of the landscape is aimed at fulfilling the economic needs, which may be done without considering the balanced values in nature, so the variation of the landscape decreases.

This paper elucidates the local knowledge of Cintaratu community on various traditional landscapes that exist in Cintaratu Village, environmental unit values related to ecology, economics, and ethics, as well as the historical influence on landscape variations in Cintaratu Village,. We hope that exploring the history of landscape changes may help conservation efforts to maintain the diversity of the landscapes and their natural resources.

\section{MATERIALS AND METHODS}

\section{Site location}

Cintaratu Village is located in the north of the capital of Parigi Sub-district, Pangandaran District, West Java, Indonesia (Figure 1), between $7^{\circ} 22^{\prime} 26.4^{\prime \prime S}$ and 108 40'39.2"E. The village, which is located about $12 \mathrm{~km}$ from the capital of the district, has an area of 1,029 hectares, having a population of 3,266 people, consisting of 1,095 households. The population density per square meter is 15 people with an annual population growth rate of $2 \%-3 \%$ per year (UNPAD, 2015). The main livelihood of the people is farming. The productions of the farming system are rice and non-rice, including coconuts, sweet potatoes, and vegetables. Some farmers work on their own land, while some other on other people's land and titisaran land, which is the land leased by the government for local village communities to make a living.

\section{Research procedure}

The method used in this study was qualitative (Creswell 1994) which is a landscape ethnobiology approach that was employed by Martin (1995), Vogel et al. (2004), Ferreira et al. (2014), Albuquerque et al. (2014) and Iskandar (2018). Some techniques including observation, participant observation, semi-structured interviews, or deep interviews with key informants were undertaken to collect the primary data in the field. The selection of informants was done purposively by using a snowball sampling technique.
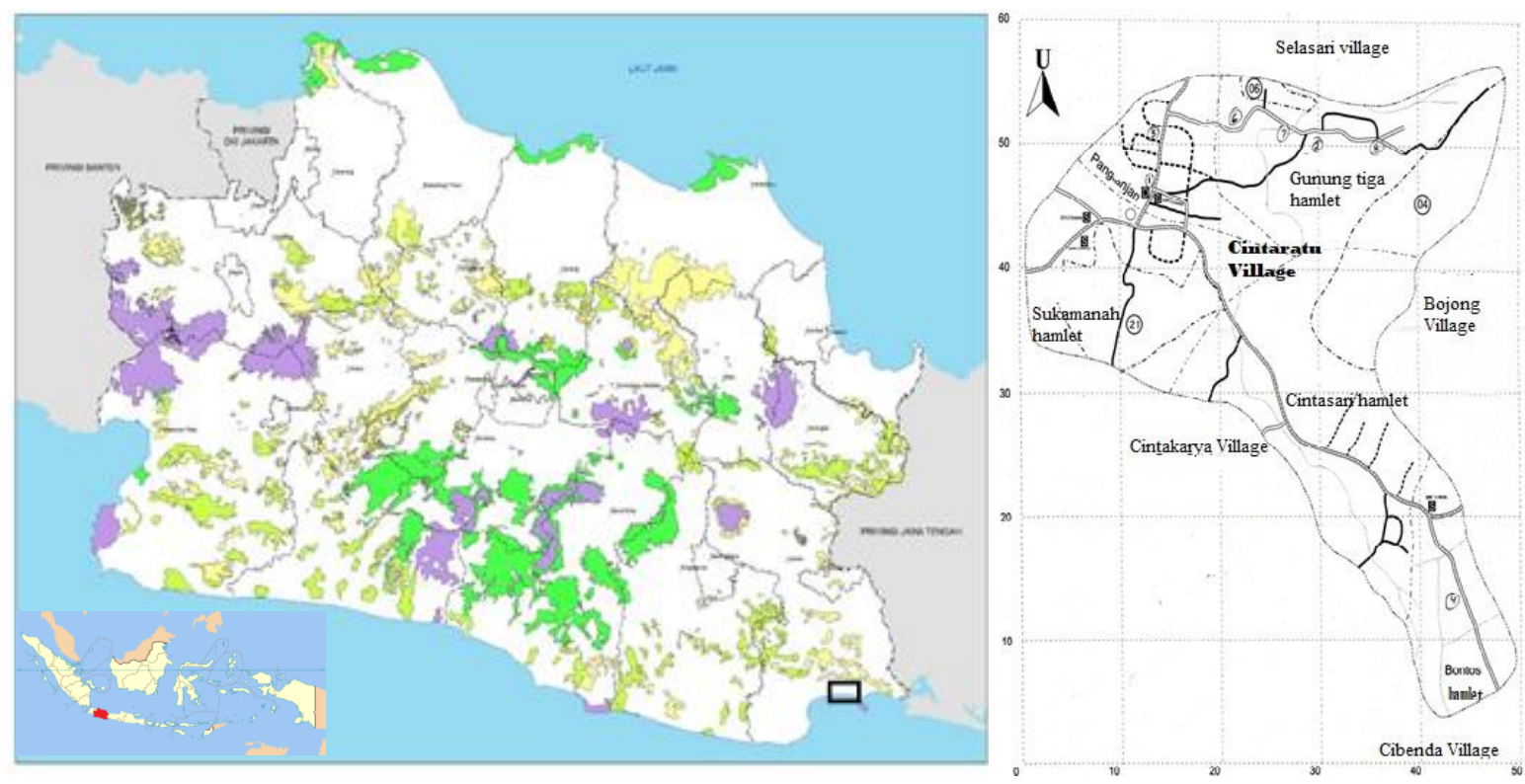

Figure 1. Research location, Cintaratu Village $(\square)$, Pangandaran District, West Java Province, Indonesia 
Observations were carried out by observing various village landscapes, including home-garden, garden, mixedgarden, rice field, river, fishpond, and forest in the study area. During the observation in each the landscape type, some dominant plant species were recorded. In addition, the structure of each general landscape and its vegetation structure was made sketch drawings. Participant observation was done by researchers, including participating in several informant activities, such as going to the garden to collect garden produce, going to the rice fields to check the water in the rice fields, going to the sacred place to pray. Semi-structured interviews were employed with informants using the interview guide. Some important points, including local names of various landscape types, main functions of each landscape type, sacred places, and ecological history of each landscape type were made in the interview guide to be used for interviewing the informants. In addition, some interesting topics that arise spontaneously in interviews were also discussed with the informants (Martin 1995).

\section{Data analysis}

Some data collected by observations, participant observation, and semi-structured interviews were analyzed in several stages, namely cross-checking, summarising, synthesizing, and making narrative (Newing et al. 2011; Iskandar 2012, 2018). The cross-checking was made to check correct data (data validation) obtained from a direct interview with informants, observation, and participant observation. The validated data were summarized, synthesized, and made narration with descriptive and evaluative analyses, while some sketch drawings of landscape structure were improved in the office and validated by information obtained informants, particularly based on an ecological story.

\section{RESULTS AND DISCUSSION}

\section{Landscape Variation in Cintaratu Village}

Based on interviews conducted with the village local community, it was found that the landscapes in Cintaratu Village were naturally formed, but because of population increase and various activities in the village to support the lives of the people, the landscape experienced changes. This is a diversity of manifestations of interaction between humans and their natural environment through the development of human society and settlements over time, under the influence of physical constraints and/ or opportunities presented by their natural environment and successive social, economic and cultural forces, both externally and internally (Mitchell and Buggey 2000). Changes that occur in the Cintaratu Village landscape were similar to those in Karangwangi where the formation of the landscape in Karangwangi was in line with village developments due to land use and management (Amelia et al. 2018). This is influenced by several additional factors, including changes in land-use policies, population increase, expansion of infrastructure development, tourism, market economic development, and reduction of forest area. Furthermore, the development of the market economy has caused changes in the behavior and lifestyle of the people of Karangwangi Village.

The people of Cintaratu Village already have traditional ecological knowledge (TEK) on the local landscapes through cultural heritage and personal experiences interacting with their environment. This is in line with the concept of the cultural landscape, i.e. about the relationship of various aspects between people, places, and identity (Cocks et al. 2017). The local community in the Village of Cintaratu recognizes various types of cultural landscapes, leuweung karamat (sacred forest), kebon (gardens), sawah/ serang (rice fields), astana (graves/tombs), pamukiman (residential areas), pekarangan (homegarden), walungan (rivers), solokan (small river), tampian (community bathing and washing area), and balong (fish pond) (Figure 2). These landscapes differ from those found in research conducted by Iskandar and Iskandar (2017) showing that based on the Baduy category, the Baduy landscapes could be divided into four types, mainly forests, huma (swidden farming), gardens and settlements. In the Village of Cintaratu there are rice fields and graves, while in the Baduy tribe there are not, because, in Baduy graves are not used as sacred places. According to their belief, after death humans will merge with nature, so they are not given a special mark. Rice fields are not found in Baduy either, because of the culture of the people to farm on dry land, so they have huma (swidden farming), instead. Based on Baduy tradition, the cultivation of wet rice-field (sawah) is prohibited. Organic farming and low external inputs and sustainable agriculture (LEISA) concepts are applied in huma system of Baduy. Therefore, the use of inorganic fertilizer and synthetic pesticides are culturally prohibited in huma system of Baduy. In addition, making fishpond is also prohibited by Baduy culture (Iskandar 1998). Therefore, the landscape types of Baduy are strongly formed by Baduy culture.

Some differences in the landscape found may be influenced by several factors including community activities, history, knowledge of the people, and natural conditions in the area. As Amelia (2018) found, the people of Karangwani village recognize various natural-cultural landscape types, i.e., leuweung (forest), huma (swidden field), wet rice fields (sawah), consisting of (i) sawah boyor (irrigated rainfed), (ii) sawah tadah hujan (nonirrigated rainfed), pekarangan (homegarden), kebon (garden), kebon campuran (mixed-garden), kebon cabe/kebon jagung (chili/ corn field), sungai (river), tambak (fish pond), and laut (sea). This shows the historical differences in the development of landscapes. In Cintaratu Village there are cultural landscapes of leuweung karamat (sacred forest), and astana (graves/ tombs), while in Karangwangi Village these cultural landscapes was not saved because the place was only visited by Prabu Siliwangi as king of the Empire of Pajajaran, and what has been saved and is believed to have magical power is a stepping stone that forms the shape of a foot hole. However, in Cintaratu Village, the place that was visited by 
Eyang Kiara Bangsa was made a leuweung karamat (sacred forest), and the place of the astana (grave/ tombs) was made a sacred site because it was the founder of Cintaratu Village. This protected sacred forest above the hamlet, in addition to preventing erosion and flooding, has magical power.

\section{Development of landscapes in the Village of Cintaratu}

The increase in population causes an increase in food and housing needs, which in turn is the driving force of changes in artificial landscapes to meet the people's needs. The landscapes are used more intensively by the community for various uses that provide more economic value. This is supported by the development of tourism areas around Cintaratu Village such as the Pananjung Pangandaran tourism area. According to Amelia et al. (2018), landscape formation is usually in line with village development because of land use and management. This is influenced by several additional factors such as changes in agricultural land policy, increasing population, expanding infrastructure development, tourism, market economic development, and decreasing regional forests. Market economic development causes changes in people's behavior and lifestyle, so it affects land use. This landscape change causes a decrease in diversity or variations in the landscape in Cintaratu Village. The changes that occur in Cintaratu Village are in line with the opinion of Farina (2010) that the landscape continues to change following changes in society, which include religion, culture, economy, politics, and environmental activities. Changes in landscapes in the Village of Cintaratu gradually began from $17^{\text {th }}$ to $21^{\text {st }}$, with massive changes beginning in the late $21^{\text {st }}$ century (Figure 3 ). Based on ecological history, the landscape changes in Cintaratu Village may be divided into six phases between 1780 and 2019, as described as follows.

\section{Changes of the landscapes in the 1780s-1920s}

Cintaratu Village initially consisted of swamps and forests. In the Village of Cintaratu, there is protected forest up to now commonly referred to as leuweung karamat, or sacred forest. The people in Cintaratu Village believe that around the 1780s three brothers came to the area that is now Cintaratu Village. The three brothers are believed to be descendants of Wali Songo from Java who came to the Cintaratu Village. As a surrogate guardian of Songo who disagreed with the Sultan of Mataram's agreement with the Dutch, who gave up Sundanese lands such as the Cisadane and Ciratum rivers, they fought with guerrilla warfare techniques. The area of the Village of Cintaratu was used by three brothers as a place to rest after a war with the Dutch. These three people are known by the name of Eyang Kiara Bangsa, Aki Balamoa, and Nyai Banawati, and each occupied a different hill in the Cintaratu Village area. Wonder Hill Jojogan is one of three hills that are believed by the people of Cintaratu Village to be a show of Eyang Kiara Bangsa leaders who are believed by the community as the first figures to come to the Gunungtilu area. At that location, the community believes, that Eyang Kiara Bangsa had lived and rested (Harja and Saeful
2018). In the forest on the hill, which is the place where Eyang Kiara Bangsa was found, there is a tomb believed by the people of Cintaratu to be the tomb of the founder of the village. This forest is protected by the community with various prohibitions or pamali. Communities are forbidden to use the forest or to extract wealth from the forest for personal gain, so the forest is still preserved for its authenticity because no community dares to use it for personal gain.

Tree species in leuweung karamat i.e., kijago (Macropanax dispermum (Blume) Kuntze), gintung (Bischofia javanica Blume), tembaga (Gluta renghas L.), lame (Alstonia scholaris R. Br.), and karaminan (Dysoxylum cauliflorum Hiern.) are believed to be very rare, and have a high economic value, but these trees can still be easily found in the leuweung karamat because there is a prohibition (pamali) to cut down or use them by the community. This is consistent with research conducted by Amelia et al. (2018) in Karangwangi Village, Cianjur, where the conservation forests are better protected due to the belief that the area is sacred and should not be disturbed. Besides, leuweung karamat is believed to have a large enough spring that is used to irrigate Cintaratu Village. This spring is believed to be related to wonder hill Jojogan, which is located near the leuweung karamat (sacred forest) because wonder hill Jojogan is believed to be connected to the upper reaches of the Citumang River. Not different from Cintaratu people who protect leuweung karamat, various indigenous tribes, such as the Dayak tribe, also protect the forest area, i.e., Tanah Ulen, with the aim of traditional preservation, as a reserve of water, timber, medicinal plants, animals and wild food plants (cf. Soedjito 2009).

Likewise, the Tengger Ranupani community, in East Java believes that with the availability of sufficient water for a variety of needs, the sustainability of crop production through maintained soil fertility, and the security of the protected function of the surrounding ecosystem are the value offered by the forests around the mountain area (Hardyanti and Judge 2014). By bio-conservation, the local wisdom of the people in Cintaratu Village views the forests as sacred forests, and consequently protect some rare plant species such as kijago, gintung, tembaga, lame, and karaminan. Likewise, in northwestern Yunnan, China, sacred forests preserve old trees and forest structures (Salick et al. 2005, 2007), and in Xishuangbanna, China, where the forest cover is reduced and fragmented, some types of vegetation, such as mountain rain forests, can now only be found on sacred hills (Huijun et al. 2002). Feng Shui Forest in Hong Kong is the only forest that is more than 60 years old which is under $500 \mathrm{~m}$ and contains a rich tree flora including several species not found elsewhere (Zhuang and Corlett 1997). These forests form the only reference point for understanding the biogeography of native ecosystems (Marafa 2003) and preserving endemic species to the island. A study of sacred forests and hunting among the Iban people of western Kalimantan, Indonesia, found that sacred sites played an important role in peoples' livelihoods (Wadley and Colfer 2004). 


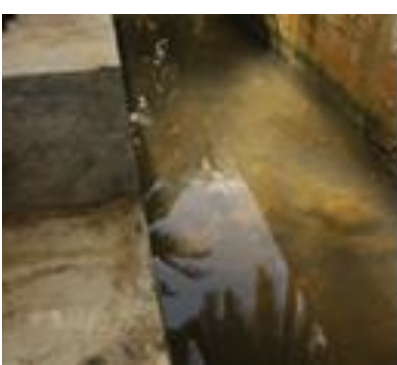

A

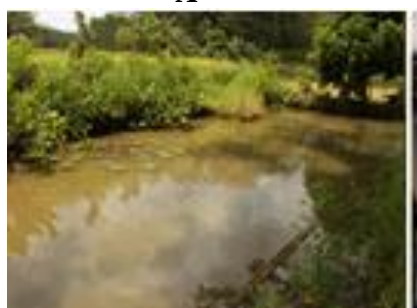

E

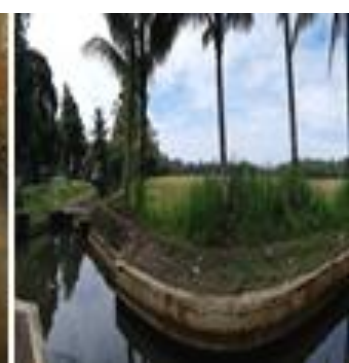

B

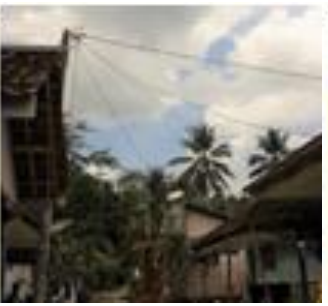

F

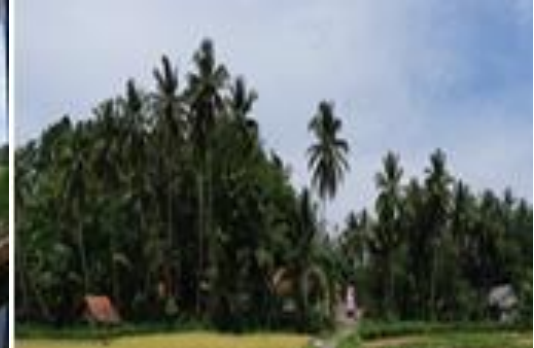

C

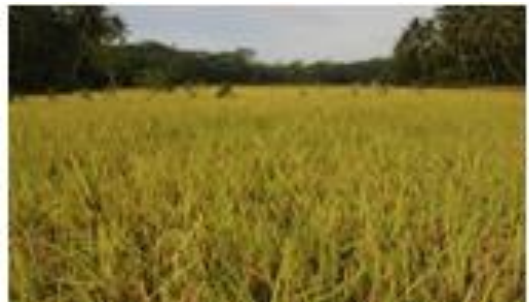

G

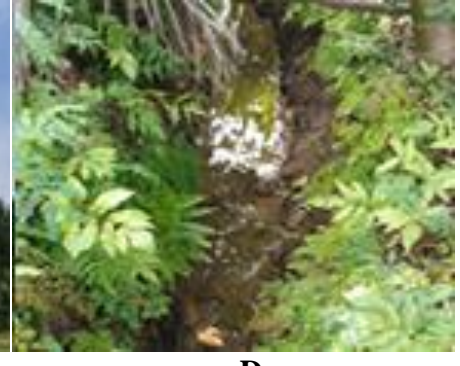

D

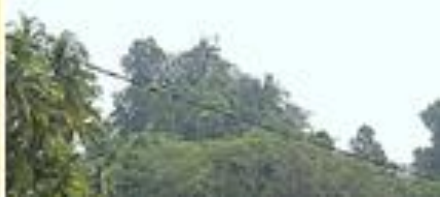

H

Figure 2. Various landscapes are found in Cintaratu, namely A. Tampian (community bathing place/ washing area), B. Walungan (rivers), C. Kebon (gardens), D. Solokan (small river), E. Balong (fish pond), F. Pamukiman (residential areas), G. Sawah/ serang (rice fields), and H. Leuweung karamat/ tombs (sacred forest)
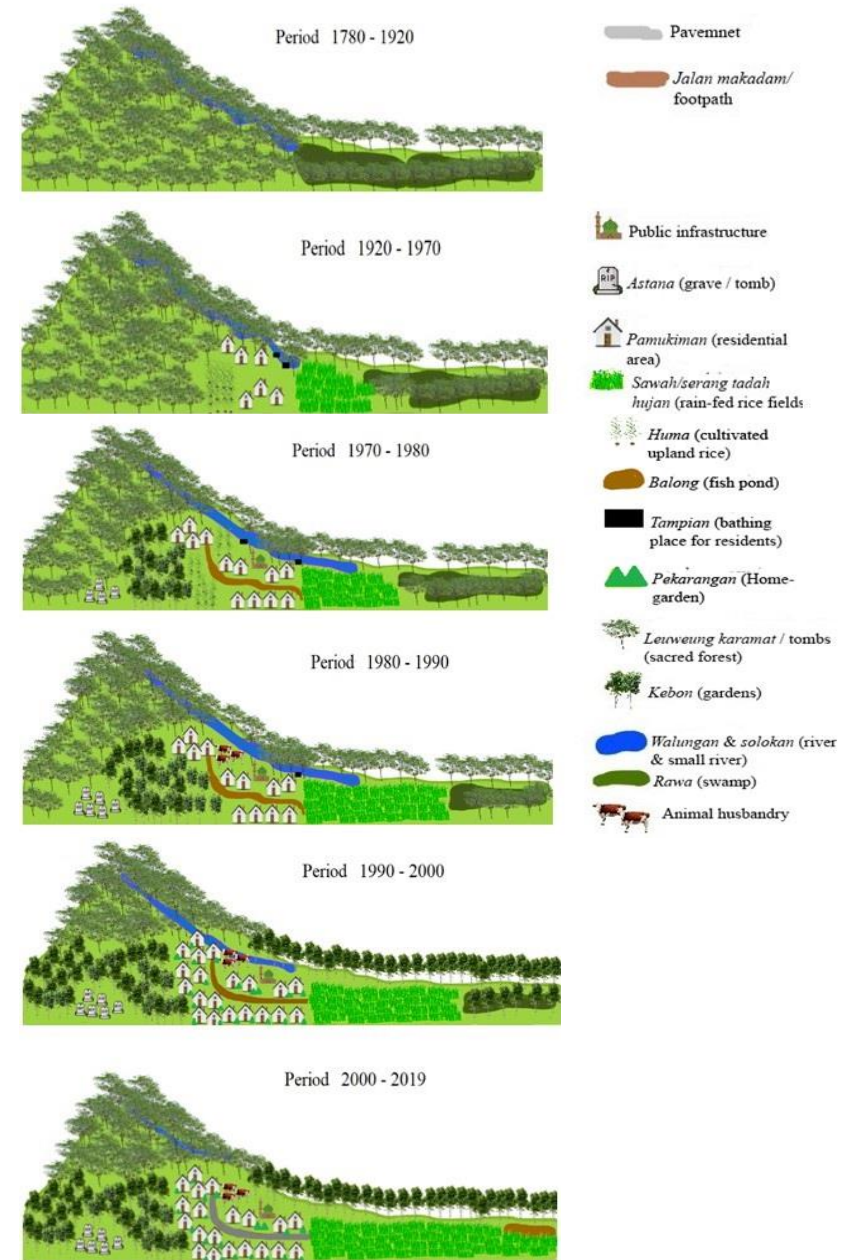

Figure 3. Changes of the landscapes in Cintaratu Village, Parigi Sub-district, Pangandaran District, West Java, Indonesia

\section{Changes of the landscapes in the 1920s-1970s}

In the period 1920s-1970s, the land was used by the community as sawah/ serang (rice fields) and huma (swidden field). Huma or rice fields are land previously forested which is then converted into swidden fields. The swidden farming (huma or ladang) system has been predominantly practiced by the village people of West Java (Iskandar 1998; Choir et al. 2018). Usually, huma is an area that is located quite uphill or hilly. The hill is called pasir by the people because the community believes that the land on the hill comes from the pasir (sand) that comes from Pangandaran beach. Huma or rice fields are usually planted with hui boleg (Ipomoea batatas L), sampeu (Manihot esculenta Crantz), and jagong (Zea mays L). Utilization of rainfed land and rain-fed rice fields is almost the same as the Sundanese ethnic communities elsewhere, on the basis of tradition, planting plants of the Araceae family, such as taro. In the Cisoka community, taro is planted in different agroecosystems, including homegarden, garden, mixed garden, and rain-fed rice fields, particularly in dry season (Mutaqin et al. 2018). In general, taro planting is done by polyculture in mixed gardens, homegarden, and garden with other plants such as corn, cassava, sweet potato, etc. However, in the wetland rice fields, the taro plants were planted monoculture by ethnic Sundanese. In addition to being used as huma, these forests are also used as settlements. Settlements are usually located near paddy fields or in sloping forest areas. However, in 1920-1970s there were still very few settlements, with residents believing that they were the original descendants of Cintaratu Village. To meet water needs, residents used dams or rivers because there were no bathrooms in each house. Walungan usually comes from springs, so the flowing water has very good quality. Public baths usually use a fairly flat area from the edge of the 
dam, which is called a tampian. Cintaratu Village has three baths, i.e., Cigirang (upstream), Citengah (middle stream), and Cihilir (downstream). Tampian is a public bathing place for the community, but it is usually used also for washing clothes and household kitchen furniture. According to Sudarmadji et al. (2016), the water flowing in a river is used for domestic purposes (including cooking, bathing, and washing) and for irrigation.

The land that was previously a swamp was then converted into rice fields, which were still using a very simple irrigation system that relied only on rain, so they were called a rain-fed rice fields. Consequently, rice cultivation was set to follow the start of the rainy season and end when the dry season started. At the start of the rainy season, farmers immediately plowed their fields using buffalo, then immediately plant rice so that at the start of the dry season the harvesting had finished.

\section{Changes of the landscapes in the 1970s-1980s}

During the period of 1970s-1980s, the construction of the Mandi-wash-latrine (MCK) was mostly carried out by the community at each house, following President Soeharto's policy on household health which was mostly conveyed by health and family planning staff. Thus, the reservoirs and tampian were rarely used by the community to bathe and dispose of feces. Besides, the construction of public infrastructure for the community was done, including irrigation and drainage (waterways) followed by the construction of bathrooms for each house, footpath, mosque, and astana (public cemetery). In line with this, people from outside the Village of Cintaratu arrived, so settlements began to multiply. Therefore, forest was increasingly converted to settlements. Huma (swidden fields) began to decrease in area. The people of Cintaratu Village converted huma into kebon (gardens). These results are in accordance with that of the research by Iskandar \& Iskandar (2016) that the kebon (garden) system itself developed from a humanitarian system such as in Karangwangi Village. The swidden field that switches its function is usually referred to as rarahan, which is prepared to be made into a kebon. Areas that are used as kebon are generally in hilly areas. Kebon (garden) location is near astana (grave) or public cemeteries which are usually at the edge of the village, with the sloping land.

\section{Changes of the landscapes in the 1980s-1990s}

The people in Cintaratu Village, besides planting plants, also started to farm livestock. Animal husbandry was carried out to meet the people's needs. Land for huma began to decrease and disappear, replaced by kebon. Paddy fields began to expand in Cintaratu Village due to the Green Revolution. The impacts of the Green Revolution caused the community to be convinced that the landscape in the form of paddy fields was more profitable because of the increasing yields of paddy rice. The high-yield varieties of rice introduced in the Green Revolution reduced harvest time to 90-100 days; therefore, three cycles of rice planting and harvesting could be carried out in a year. The same thing happened in Karangwangi Village, Cianjur District, where farmers began to know new varieties of rice, so local rice was increasingly scarce and disappeared (Amelia and Iskandar, 2017). According to the community, replacing them with short-age rice varieties caused yields to increase quite high within one year. Besides, farmer groups began to form which made it easier for farmers to manage their rice fields. Rice fields began to use an irrigation system with the help of pipes or water channels made of bamboo poles, which were perforated and connected so that they could bring water from springs or rivers to rice fields. Introduction of the Green Revolution and Panca Usaha Tani (Five Farming Programs) by the government led to the uniformity of farmers in conducting agricultural businesses. The five farming programs were as follows: (i) the modern use of rice varieties, such as IR, PB, and other genetically engineered seeds from the laboratory; (ii) the use of inorganic fertilizers, such as urea, TSP, etc.; (iii) the increased preparation of land (using pesticides); (iv) the increased irrigation; and (v) the increased crop maintenance. The implementation of the Green Revolution Program has had a significant impact on agricultural life in the village.

During this period, the development of public infrastructure for the community progressed. The rapid development of public infrastructure in Cintaratu Village has led to the rapid advancement of this village. These developments included the establishment of Puskesmas (community health centers), PKK buildings (family welfare empowerment), and Posyandu (integrated service posts) so many forest lands were converted into residential areas and supporting facilities.

\section{Changes of the landscapes in the 1990s-2000s}

During this period public infrastructure development had progressed. Many kebon were converted into residential lands. In addition, kebon was increasingly being used, especially coconut plantations, with palm juice taken as raw material for coconut sugar. The nira artisans, also used coconut to be taken as copra or young coconut material sold to tourist attractions in Pananjung Pangandaran. But some of the palm tree craftsmen turned to coconut collectors. The kebon (garden), was also planted with annual plants of high economic value including albasia (Paraserianthes falcataria (L) I.C. Nielsen), mahogany (Swietenia mahagoni (L) Jacq), and teak (Tectona grandis L). This is consistent with the results of Amelia and Iskandar's research (2017) that in the 2000s, the Ministry of Forestry issued a reforestation policy, by encouraging communities to plant trees with high economic value, such as albasia and mahogany. In addition, more intensive farming, carried out elsewhere in West Java such as the people of Karangwangi Village, Southern Cianjur was adopted and albasia was planted in the huma farming system which was originally introduced by the Forestry Office through the regreening program (Iskandar et al. 2017. Besides, the people of Cintaratu Village planted bananas (Musa $\mathrm{x}$ paradisiaca) in kebon because they quickly produce fruit and can be harvested throughout the year. Bananas have traditionally been farmed in various agroecosystems of West Java, including in homegardens, swidden, gardens, and mixed gardens 
instead of commercially farmed in the banana plantation (Karyono 1981; Iskandar and Iskandar 2011; Iskandar and Iskandar 2015).

In general, the produce of kebon is sold to collectors or consumed by the people of Cintaratu Village themselves. Coconut is only taken by the fruit and then sold to collectors from other villages as well as bananas. Trees in the form of timber are used for community development purposes in Cintaratu Village, such as albasia, mahogany, and teak, only a small portion is sold.

\section{Changes of the landscapes in the 2000s-2019}

More and more land was needed for housing, so, to fulfill those needs, part of the unmanaged plantation land was converted into a residential area. Reuma is a kebon that is no longer used. According to Amelia \& Iskandar (2017), reuma is jami or secondary forest that has been left or abandoned for a year, while secondary forest called jami is a huma that has just been left or cut down for less than one year and still has rice straw remaining on it. Community housing is usually referred to as pamukiman. More settlements were found in all parts of the village because the price of land was quite cheap, so a lot of migrants came to Cintaratu Village. Usually, every mosque has an empty land in front of it which is commonly referred to as a yard. Pakarangan itself is usually used by the community as a place to grow vegetables such as cengek (Capsicum frutescens L) or herbs. The plots of land in Cintaratu Village generally tend to have lower diversity of plant species than the home-gardens in semi-urban areas such as in Sukapura village, Bandung, which have many species of vegetable crops, including corn (Zea mays L), cassava (Manihot esculenta Crantz), banana (Musa x paradisiaca $\mathrm{L})$, tomato (Solanum lycopersicum L), ginger (Zingiber officinale Roscoe), sand ginger / Kaempferia galanga L), tumeric / koneng (Curcuma domestica Valeton), sweet potato / hui boled (Ipomoea batatas L), peanut (Arachis hypogaea L), and lemongrass (Cymbopogon citratus (DC) Stapf) (Prihatini et al. 2018).

Due to the increasing population of Cintaratu Village with the increasing number of migrant communities, the tampian began to be capped or cemented and was shaped like a bathing pool. According to the community, the cementing of the tampian Cigirang caused the tampian Citengah to become dry, so it could not be used. Now, in general, tampian is no longer used by residents, because almost every house already has a bathroom. At this time, because they are not used anymore, they are switched to balong or pond. Balong is a pond for raising fish, with the aim that the community does not need to buy from outside Cintaratu Village.

There are 13 types of traditional landscapes in the Cintaratu area based on the changes during the period from 1780s to 2019 (Table 1, Figure 3). The diversity of traditional landscape types increases in line with the number of human activities in meeting their needs. In the beginning, the landscapes were forest and swamp, but the landscapes changed after the arrival of three brothers who were believed by the Cintaratu community to be the founders of Cintaratu Village. In the 1920s-1970s, rice fields were formed by changing swamp into rice fields. However, the formation of settlements was more clustered on forest land bordering the swamps. Those areas, besides being made into settlements, were also used as huma, as a place to grow crops to meet the main food needs of the people of Cintaratu Village. In the village area close to the river, a public bathing place was built. The diversity of traditional landscapes increased in the 1970s-1990s period because the community increased the conversion of forest land huma into gardens in the period 1980s-1990s. Increased land conversion and intensification of land use were done to produce food to meet their needs. In addition, in the same period, the forest that was in the top of the hill was made a sacred forest because it was believed to be the patilasan of the Eyang Kiara Bangsa. The hilltop area became the leuweung karamat and at the same time conserved plants in the area. This is the local wisdom of the community in protecting their area, because the area is above settlements and gardens to avoid landslides. Besides, the leuweung karamat area is a water catchment area and upstream of the Citumang river that is often used by the community. This is in line with the general designation of leuweung karamat in various indigenous tribes, for example in the Dayak tribe which has a term for a local forest area that is being preserved, i.e., Tanah Ulen. The forest is preserved traditionally, as reserves of timber, medicinal plants, animals and wild food plants, and water sources (cf. Soedjito 2009). According to Dudley et al. (2010), sacred forests are remnants of forests, often the only natural or semi-natural place left in the cultural landscape. In highly modified landscapes in much of Asia, sacred forests often contain the only remnant of the original ecosystem, although they often undergo changes naturally.

In the period of 1980s-1990s, the Panca Usaha Tani program, by increasing intensive paddy field farming, resulted in the conversion of swamps to paddy fields, so from 2000s to 2019, swamps were no longer found. Correspondingly, the forest and kebon were converted into monocultures, such as coconut plantations (Cocos nucifera L.), albasia, mahogany, and teak. This phenomenon also happened in several places in southern West Java such as in Karangwangi Village (Iskandar et al. 2017; Amelia and Iskandar 2017). Because much of the land was converted from forests and gardens into coconut plantations, the Cintaratu Village region became one of the highest producing areas in the Pangandaran District. 
Table 1. Landscape changes in Cintaratu areas between 1780s and 2019

\begin{tabular}{|c|c|c|c|c|c|c|}
\hline \multirow{2}{*}{ Landscape types } & \multicolumn{6}{|c|}{ Periods } \\
\hline & 1780s-1920s & 1920s-1970s & 1970s-1980s & 1980s-1990s & 1990s-2000s & 2000 s-2019 \\
\hline Leuweung (Forest) & + & + & & & & \\
\hline Rawa (Swamp) & + & + & + & + & & \\
\hline Leuweung karamat (Sacred forest) & & & + & + & + & + \\
\hline Dusun/kampung (Hamlet) & & + & + & + & + & + \\
\hline Tampian (Community bathing place) & & + & + & + & & \\
\hline Huma (Swidden farming) & & + & + & & & \\
\hline Kebon (Garden) & & & + & + & & \\
\hline Pekangan (Homegarden) & & & + & + & + & + \\
\hline Kebon monokultur (Monoculture garden) & & & & & + & + \\
\hline Sawah (Paddy field) & & + & + & + & + & + \\
\hline Astana (Graves/tombs) & & & + & + & + & + \\
\hline Ternak (Animal farming) & & & & + & + & + \\
\hline Balong (Fishpond) & & & & & & + \\
\hline Total & 2 & 7 & 10 & 10 & 8 & 9 \\
\hline
\end{tabular}

\section{Landscape conservation efforts by the community}

The most influencing factor in land use changing is human activity in extracting natural resources in order to meet both daily and long-term needs. This is consistent with the opinion of Putra and Satiawan (2018) that the high population growth and the increasing demands of the community's need for land often resulted in conflicts of interest in land use and differences between the actual land use and its intended use. Because of this land-use change, there has been a reduction in forest land because it has been traditionally converted to other forms of landscape. These changes add to the diversity of landscapes in Cintaratu Village. Increased landscape diversity should be able to increase the diversity of species that inhabit it. However, if more land is converted into agricultural land, especially monocultures and community settlements, the biodiversity in the landscape will decline. Thus, it seems that in Cintaratu Village there has been an increase in landscape diversity by reducing forest area. Forest loss on a limited scale of the forest has resulted in a reduction in the biological resources it contains. According to Van Noordwijk et al. (2003), mountainous areas and forests play a role in storing rainwater, as well as preventing floods and droughts. In addition, the forest is also a habitat for flora and fauna. If there is a change in the landscape from the forest to agricultural land, in addition to the loss of the function of the forest as a water catchment area, the flora and fauna in the forest will lose their habitat.

Conservation is an effort to manage natural resources that guarantees their wise use for both present and future generations so that the quality and preservation of natural resources and the environment can be maintained to ensure sustainable development. Rachman (2012) added that the conservation goals are (i) realizing the conservation of biological resources and the balance of their ecosystems so that they can better support efforts to improve the welfare and quality of human life, and (ii) preserving the ability and utilization of biological resources and their ecosystems in a harmonious manner. In addition, conservation is an effort to preserve wildlife. Without conservation, large- scale landscape changes will cause damage to the natural habitat of animals. The destruction of this natural habitat has resulted in human and animal conflicts, which will harm both parties. For example, because of human conflict with wildlife, especially the attacks of predatory animals on livestock or the damage of agricultural land due to wild animals, humans will hunt the animals in various ways, from capturing directly, trapping, even poisoning which results in the death of these animals. On the other hand, humans will suffer losses because animals play a role in ecological balance, especially in controlling populations of other animals that act as pests.

The community carries out conservation efforts on the surrounding natural resources based on their knowledge. This knowledge is often related to the history that developed in their respective regions. The same thing happened in Cintaratu Village where the community has a sacred landscape called leuweung keramat/ tomb. Cintaratu Village itself has a prohibition or pamali about this forest, which is believed to be a sacred forest, and its authenticity must not be disturbed. As a result of the belief, the community does not overuse the biological wealth in the forest. People believe that if they use the natural resources in the forest for their own needs, they will get a curse. The elders of Cintaratu Village protect areas that are very important for the continuity and preservation of their territory such as forests that are located in the highlands above the settlement wrapped in myth. Something similar is done by the Mankon people who have developed interesting myths about their belief in the sacred forest and the magical powers that live in the forest (Angwafo). According to Oates, (1999), Tchamou, (2007), and Sherpa et al. (2013) myths are secrets transmitted from generation to generation that highlight victories due to sacred forests during tribal wars or misfortune that befall lawbreakers, who disobey the command of the sacred forest. Myth instills traditional fears that have grown from time to time and have gone a long way to ensuring the protection of sacred forests and other natural resources. 
This also results in old-growth timber species to persist whereby it is considered to be locally extinct elsewhere. In Cintaratu, we can still find kijago, gintung, tembaga, lame, and karaminan. But regardless of community belief, if examined carefully, actually by protecting the forests there, the community gets many benefits such as the supply of water and oxygen, the prevention of soil erosion, and the protection of the flora and fauna. The cultural landscape often reflects specific techniques of sustainable land use, taking into account the characteristics and boundaries of the natural environment in which they are found, and certain spiritual relationships with nature. The protection of the cultural landscape can contribute to modern techniques of sustainable land use and can maintain or enhance natural values in the landscape. The sustainability of traditional forms of land use supports biodiversity because the protection of traditional cultural landscapes is very helpful in maintaining biodiversity (Mitchell and Buggey 2000). Likewise, Massiri et al. (2016) say that forests are regulators of water management, erosion and landslide protection, and climate. Nagel (2011) also states that forests can also retain potential energy from falling rainwater, so the water flow is not too large, preventing erosion on the soil, in addition to their function as a buffer of water systems in a watershed.

In addition to conserving the forest area, the Cintaratu Village community also conserves hills or areas near watercourses. In the hilly areas, even though the forest was then converted to a forest and has now become a garden, the people still plant the hill with trees. The community planted the hilly area because of economic interests, but as a result, the community also carried out conservation of the land. According to Rachman (2012) trees have multiple functions. Logs contain many chemicals such as lignin, cellulose, glucose, and others. Also, timber trees have economic value when used, such as albasia, mahogany, and teak. Tree roots grip the soil to bind nutrients in the soil and strengthen the soil. Some roots can also be used for medicines and a staple food for humans. The function of roots is important, which is storing water in the rain and the stored water will continue to flow throughout the year; besides, roots also prevent landslides.

Based on this study it can be concluded that ten village landscapes, i.e., leuweung karamat (sacred forest); kebon (garden), sawah (rice field), astana (grave/ tomb), pamukiman (residential area), pekarangan (homegarden); walungan (river), solokan (small river), tampian (bathing and washing place for residents), and balong (fish pond) are documented in Cintaratu Village. These village landscapes may be divided into natural landscapes and man-made landscapes. Some landscapes, i.e., leuweung karamat and solokan are natural, while the rest of landscape types are considered as man-made landscapes.

Based on ecological history, it has been revealed that village community behaviors have changed the landscapes in Cintaratu Village. Some socioeconomic factors, including the increasing human population, market economic penetration, and government policy have changed the landscape types of Cintaratu Village. Therefore, generally, the landscape types of Cintaratu have dynamically changed because of human activities (anthropogenic factors) instead of natural phenomena.

Conservation efforts carried out by the people themselves towards the traditional landscape are usually associated with a customary prohibition or pamali that develops in the village community of Cintaratu. Therefore, it can be predicted, as long a pamali tradition can be traditionally maintained, the sacred place can be maintained by the local community based on the local knowledge embedded by culture, particularly belief system.

\section{ACKNOWLEDGEMENTS}

The authors would like to thank the village head administration of Cintaratu Village and the people in Cintaratu Village who have supported this research. This paper publication is supported by ALG (Academic Leadership Grant) program of Prof. Johan Iskandar, with the main topic is titled "Ethnobiology for the People Welfare to support the Sustainable Development". Therefore, the authors would like to thank Rector of Universitas Padjadjaran, Sumedang, Indonesia who has supported the publication. We would also like to thank Ethnobiology Team of Biology Department, Faculty of Mathematics and Natural Sciences, Universitas Padjadjaran who have supported in collecting the field data.

\section{REFERENCES}

Agnoletti M. 2014. Rural landscape, nature conservation, and culture: some notes on research trends and management approaches from a (southern) European perspective. Landsc Urban Plan 126: 66-73.

Albuquerque UP, Cruz da Cunha LVF, Lucena RFP, Alves RRN. (eds). 2014. Methods and techniques in ethnobiology and ethnoecology. Springer Science \& Business Media, New York.

Amelia F, Iskandar J, Partasasmita R, Malone N. 2018. Recognizing indigenous knowledge of the Karangwangi rural landscape in South Cianjur, Indonesia for sustainable land management. Biodiversitas 19 (5): 1722-1729.

Amelia FUD, Iskandar J. 2017. Local knowledge about the structure, function, and conversion of landscape in the Karangwangi Village, Cianjur, West Java, Indonesia. IOP Conf. Ser.: Earth Environ Sci 91 (1): 012019. DOI: 10.1088/1755-1315/91/1/012019

Angwafo TE, Fru BS, Chefor F. 2016. Contribution of traditional institutions to the sustainable management of sacred forests: A case study of Mankon sacred forests northwest region, Cameroon. J Biol Environ Sci 9 (4): 1-19.

Antoko BS, Sanudin, Sukmana A. 2008. Change in forest function in Asahan district, North Sumatera. Info Hutan. V (4): 307-316. [Indonesian]

Antrop M. 1997 The concept of traditional landscapes as a base for landscape evaluation and planning: the example of Flanders Region. Landsc Urban Plan 38: 105-117.

Berkes F. 2008. Sacred Ecology. 2nd ed. Routledge, New York,.

Choir IR, Iskandar J, Parikesit, Partasasmita R, Husodo T, Kumoro J, Megantara EN. 2018. The local management and sustainability of swidden farming in the Villages of 
Bojongsalam and Sukaresmi, Upper Cisokan Watershed, West Java, Indonesia. Biodiversitas 19: 1054-1065

Cocks M, Vetter S, Wiersum KF. 2017. From universal to local: perspectives on cultural landscape heritage in South Africa. Intl J Heritage Stud. DOI: 10.1080/13527258.2017.1362573

Davidson-Hunt IJ. 2003. "Indigenous lands management, cultural landscapes, and Anishinaabe people of Shoal Lake, Northwestern Ontario, Canada. Environments 31: 21-40.

Droste BV, Plachter H, Rössler M. 1995. Cultural landscapes of universal value: components of a global strategy. UNESCO, Paris.

Dudley N, Bhagwat S, Higgins-Zogib L, Lassen B, Verschuuren B, Wild R. 2010. Conservation of biodiversity in sacred natural sites in Asia and Africa: A review of the scientific literature. In: Verschuuren B, Wild R, McNeely J, Oviedo G (eds.), Sacred Natural Sites: Conserving Nature and Culture. Taylor and Francis.

Fuentes A, Baynes-Rock M. 2017. Anthropogenic landscapes, human action, and the process of co-construction with other species: making anthromes in the Anthropocene. Land 6 (1): $1-15$.

Hardyanti SA, Hakim L. 2014. Local people's knowledge about plant trees species inside the tropical forest of Tengger Ranupani. J Biotropika 2 (1): 1-7. [Indonesian]

Harja S, Sunaedi N. 2018. Societies' participation in managing Wonder Hill Jojogan as a tourist destination in Cintaratu Village Parigi Sub-district Pangandaran District. [Report] Department of Geography Education, Faculty of Teacher Training and Education, Siliwangi University, Tasikmalaya. [Indonesian]

Hreško J, Kanásová D, Petrovič F, 2010. Landscape archetypes as the elements of Slovak historical landscape structure. Ekológia (Bratislava) 29 (2): 158-173.

Iskandar J, Iskandar BS, Partasasmita R. 2017. Introduction of Paraserianthes falcataria in the traditional agroforestry 'huma' in Karangwangi Village, Cianjur, West Java, Indonesia. Biodiversitas 18: 295-303.

Iskandar J, Iskandar BS, Partasasmita R. 2018. Site selection and soil fertility management by Outer Baduy people (Banten, Indonesia) in maintaining swidden cultivation productivity. Biodiversitas 19 (4): 1334-1346.

Iskandar J, Iskandar BS. 2011. Agroecosystem of Sundanese People. PT Kiblat Buku Utama, Bandung. [Indonesia]

Iskandar J, Iskandar BS. 2015. Study on botany regarding the diversity of food plants in the swidden farming system in supporting of food safety of the Baduy community. Pros Sem Nas Masy Biodiv Indon 1 (6): 1265-1272.

Iskandar J, Iskandar BS. 2017. Local knowledge of the Baduy Community of South Banten (Indonesia) on the traditional landscapes. Biodiversitas 18 (3): 928-938.

Iskandar J. 1998. Swidden Cultivation as a Form of Cultural Identity: the Baduy Case. [Dissertation], University of Kent at Canterbury, England.

Iskandar J. 2012. Ethnobiology and sustainable development. AIPI Bandung, Puslitbang KPK LPPM Universitas Padjadjaran. [Indonesia]

Iskandar J. 2018. Ethnobiology, Ethnoecology, and Sustainable Development. Plantaxia, Yogyakarta. [Indonesian]

Johnson LM, Hunn ES (eds). 2012. Landscape ethnoecology: concepts of biotic and physical space. Berghahn Books, New York.

Karyono. 1981. Structure of Homegardens in Village of Citarum River Basin. [Dissertation]. Padjadjaran University, Bandung. [Indonesian]

Marafa L. 2003. Integrating natural and cultural heritage: the advantage of feng shui landscape resources. Intl J Heritage Stud 9:307-323
Massiri SD, Nugroho B, Kartodihardjo H, Soekmadi R. 2016. Preference and motivation of local communities in utilizing forest resources in Lore Lindu National Park, Central Sulawesi Province. Jurnal Manusia Lingkungan 23 (2) : 215223. [Indonesian]

Mitchell N, Buggey S. 2000. Protected landscapes and cultural landscapes: taking advantage of diverse approaches. The George Wright Forum 17 (1): 35-46.

Mojses M, Petrovič F. 2013. Land-use changes of historical structures in the agricultural landscape at the local levelHriňová case study. Ekologia (Bratislava) 32 (1): 1-12.

Mutaqin AZ, Fatharani M, Iskandar J, Partasasmita R. 2018. Utilization of araceae by local community in Cisoka Village, Cikijing Sub-district, Majalengka District, West Java, Indonesia. Biodiversitas 19: 560-571.

Nagel PJF. 2011. Forest preservation in relation to the environment and economic potential. Proceeding PESAT (Psikologi, Ekonomi, Sastra, Arsitektur \& Sipil) 4: 1-7.

Newing H, Eagle CM, Puri RK, Watson CW. 2011. Conducting research in conservation: social science methods and practice. Routledge Taylor Francis Group, London and New York.

Noordwijk VM, Farida B, Verbist, Tomich TP. 2003. Agroforestry and watershed functions of tropical land-use mosaics, The Second Asia Pacific Training Workshop on Ecohydrology, Cibinong, Bogor.

Oates JF. 1999. Myth and reality in the rain forest: how conservation strategies are failing in West Africa. University of California Press, Berkeley, CA, USA.

Oksana, Irfan M, Huda MU. 2012. The effect of the conversion of forest land into oil palm plantations on the chemical nature of the soil. J Agroteknologi 3 (1): 29-34. [Indonesian]

Partasasmita R, Iskandar J. Malone N. 2016. Karangwangi people's (South Cianjur, West Java, Indonesia) local knowledge of species, forest utilization, and wildlife conservation. Biodiversitas 17: 154-161.

Pratami D, Pramukanto Q. 2017. Planning of cultural landscape conservation of Outer Baduy and Dangka Tribes with bioregion approach. Jurnal Arsitektur Lansekap 3 (2): 223233. [Indonesian]

Prihatini J, Iskandar J, Partasasmita R, Nurjaman D. 2018. The impacts of traditional homegarden conversion into the commercial one: a case study in Sukapura Village of the Upstream Citarum Watershed, West Java, Indonesia. Biodiversitas 19: 1926-1940.

Putra ASP, Satiawan PR. 2018. Formulation of changes in land use due to the construction of the Waru-Juanda toll road in Tambakoso Village, Sidoarjo District. J Teknik ITS 7 (2):1-7. [Indonesian]

Rachman M. 2012. Conservation of values and cultural heritage. Indonesian J Conserv 1 (1): 30-39. [Indonesian]

Rusdi, Alibasyah MR, Karim A. 2013. Land degradation due to erosion in agricultural areas in Lembah Seulawah sub-district, Aceh Besar district. J Manajemen Sumberdaya Lahan. 2 (3): 240-249. [Indonesian]

Salick J, Amend A, Anderson D, Hoffmeister K, Gunn B, Zhengdong F. 2007. Tibetan sacred sites conserve old growth trees and cover in the eastern Himalayas'. Biodiv Conserv 16: 693-706

Salick J, Yongping Y, Amend A. 2005. Tibetan land use and change near Khawa Karpo, Eastern Himalayas. Econ Bot 59: 312-325

Sauer CO. 1963. "The morphology of the landscape. In land and life: a selection from the writings of Carl Ortwin Sauer. University of California Press, Berkeley, CA.

Sherpa PD. Gelu S, Khim G, Lama K. 2013. Revitalizing customary governance \&strengthening traditional knowledge of natural resource management in Nepal. In: Indigenous 
Peoples, Forests \& REDD plus: Sustaining \& Enhancing Forests Through Traditional Resource Management 11 (2): 196-268.

Tchamou N. 2007. Sacred Forests and Community Forests at the Crossroads for Biodiversity Conservation in Central Africa: a case study of Cameroon. [Thesis]. Columbus University, Picayune, USA.

Treves A, Wallace RB, White S. 2009. Participatory planning of interventions to mitigate human-wildlife conflicts. Conserv Biol 23 (6): 1577-1587.
Unpad. 2015. Cintaratu Parigi Pangandaran Village. http://kknm.unpad.ac.id/cintaratu [Indonesian]

Verbist B, Putra AE, Budidarsono S. 2004. Causes of land-use change and its effect on watershed areas (DAS) in coffeebased agroforestry landscapes in Sumatera. Agrivita 26 (1): 29-38. [Indonesian]

Zhuang XY, Corlett RT. 1997. Forest and forest succession in Hong Kong, China. J Trop Ecol 13 (6): 857-866. 